\title{
Identification of 'Prata anã' banana leaf to diagnose the level of phosphorus sufficiency
}

\author{
José Tadeu Alves da Silva ${ }^{1} \&$ Maria Geralda Vilela Rodrigues ${ }^{2}$
}

\begin{abstract}
The aim of this study was to identify the leaf and its part with greater sensitivity to detect $P$ variation in the 'Prata anã' banana plant. The experiment was carried out in Montes Claros, Minas Gerais, in a clayey Oxisol. A randomized complete block design was used, with six P doses $(0$, $50,100,150,200$ and $250 \mathrm{~g}$ family $^{-1}$ year ${ }^{-1}$ of $\mathrm{P}_{2} \mathrm{O}_{5}$ ) and four replications. In the plants beginning the emission of the bunch in the first, second and third cycle of the banana tree, the $3^{\text {rd }}$ and the $7^{\text {th }}$ leaves were collected from the apex, from where $10 \mathrm{~cm}$ of the center of the limbs were removed, eliminating the midrib, $10 \mathrm{~cm}$ of the petiole and $10 \mathrm{~cm}$ from the midrib and $10 \mathrm{~cm}$ from the 1 leaf limbs. The midrib of the third leaf showed greater sensitivity to detect the variation of the P content in the banana tree when the content of this nutrient varies in the soil, and can be indicated to be used in the diagnosis of P in the 'Prata anã' banana tree. The third leaf limb from the apex is not the part of the leaf indicated to perform the diagnosis of P in the banana 'Prata anã' as recommended in the literature.
\end{abstract}

Index terms: Leaf sampling, foliar analysis, nutritional diagnosis.

\section{Identificação da folha da bananeira 'Prata anã' para diagnóstico do nível de suficiência de fósforo}

Corresponding author: josetadeu@epamig.br

Received: June 08, 2018 Accepted: September 21, 2018

Copyright: All the contents of this journal, except where otherwise noted, is licensed under a Creative Commons Attribution License.
Resumo - O objetivo desse trabalho foi identificar a folha e a parte dela com maior sensibilidade para detectar a variação do teor de $\mathrm{P}$ na bananeira 'Prata anã'. O experimento foi realizado em Montes Claros, Minas Gerais, em Latossolo Vermelho amarelo, argiloso. O delineamento experimental foi de blocos casualizados, com seis doses de $\mathrm{P}\left(0,50,100,150,200\right.$ e $250 \mathrm{~g}_{\text {família }}{ }^{-1}$ ano $^{-1}$ de $\mathrm{P}_{2} \mathrm{O}_{5}$ ) e quatro repetições. Nas plantas iniciando a emissão do cacho no primeiro, segundo e terceiro ciclo da bananeira coletaram-se a $3^{\mathrm{a}}$ e a $7^{\mathrm{a}}$ folhas a partir do ápice, de onde foram retirados $10 \mathrm{~cm}$ do centro do limbo, eliminando-se a nervura central, $10 \mathrm{~cm}$ do pecíolo, $10 \mathrm{~cm}$ da nervura central e $10 \mathrm{~cm}$ do limbo da folha 1 . Verificou-se que a nervura central da $3^{\mathrm{a}}$ folha apresentou maior sensibilidade para detectar a variação do teor de P na bananeira quando o teor desse nutriente varia no solo, podendo ser indicada para ser utilizada na diagnose de P na bananeira 'Prata anã'. O limbo da $3^{\mathrm{a}}$ folha a partir do ápice não é a parte da folha indicada para utilizar na diagnose de P na bananeira 'Prata anã', como preconizado na literatura.

Termos para indexação: Amostragem foliar, nutrição de planta, diagnose nutricional. 
The International Reference Method for Sampling (MEIR), proposed by Martin-Prével (1974), consists of sampling part of the $3^{\text {rd }}$ leaf limb from the apex, with inflorescence at the stage of all female bunch uncovered (without bracts) and presenting up to three bunches of male flowers. For the 'Prata anã' banana, Silva et al. (1999) recommended to collect the leaves according to the MEIR method, adapting it to plants at the beginning of the bunch emission.

The limb of the 3rd leaf proposed by Martin-Prével (1974) presents high sensitivity to detect the variation of nitrogen $(\mathrm{N})$ and potassium $(\mathrm{K})$ in the plant (SILVA et al., 2003). However, Silva and Rodrigues (2013) verified that the application of $\mathrm{P}$ increased its content in the soil and did not influence the content in the limb of the $3^{\text {rd }}$ leaf of the 'Prata anã' banana, in four banana cycles. According to these authors, this part of the leaf may not be suitable for use in the diagnosis of $\mathrm{P}$ content in the banana tree. Bolfarini et al. (2016) found Similar results. For Lahav and Turner (1983), the analysis of the petiole or the midrib may be better than that of the limbs to diagnose the $\mathrm{P}$ content in the banana tree. Rodrigues et al. (2010) found that the collection of the above leaf (leaf 2) or below (leaf 4) of the recommended leaf (Leaf 3) does not alter the leaf contents in relation to the indication of the MEIR method, thus tolerating a possible variation of the sample to the position.

The inadequate diagnosis of $\mathrm{P}$ content in the banana tree can lead to an error in the recommendation of this nutrient, leading to unnecessary applications of $\mathrm{P}$ in the banana tree, increasing the cost of production and nutritional imbalance in the crop. The aim of this study was to identify the leaf and its part with the highest sensitivity to detect the variation of $\mathrm{P}$ in the 'Prata anã' banana tree when its soil content changes.

The experiment was carried out at the Experimental Farm of EPAMIG in Montes Claros, Minas Gerais (Longitude: $-16^{\circ} 44^{\prime} 6 \mathrm{~S}$ and Latitude: $-43^{\circ} 51^{\prime} 42 \mathrm{O}$ ), in a clayey Oxisol with the following chemical attributes in the $0-0.20$ m layer: $\mathrm{pH}$ in $\mathrm{H}_{2} \mathrm{O}=6.2$; organic matter $=2.4$ dag $\mathrm{kg}^{-1}$; remaining phosphorus $=18.4 \mathrm{mg} \mathrm{L}^{-1} ; \mathrm{P}-$ Mehlich $1=4.6 \mathrm{mg} \mathrm{dm}^{-3} ; \mathrm{K}-$ Mehlich $1=138 \mathrm{mg} \mathrm{dm}^{-3} ; \mathrm{Al}=0.0$ cmolc dm ${ }^{-3} ; \mathrm{Ca}=5.5 \mathrm{cmol}_{\mathrm{c}} \mathrm{dm}^{-3} ; \mathrm{Mg}=1.2 \mathrm{cmol}_{\mathrm{c}} \mathrm{dm}^{-3}$.

Plant tissue seedlings of the 'Prata Anã' banana tree were planted in spacing of $2.5 \mathrm{~m} \times 3.0 \mathrm{~m}$. The experimental plots consisted of 20 families and the useful plots consisted of six banana families. The experimental design was randomized blocks, with six $\mathrm{P}$ doses $(0,50$, $100,150,200$ and $250 \mathrm{~g}$ family $^{-1}$ year $^{-1}$ of $\mathrm{P}_{2} \mathrm{O}_{5}$ ) and four replications. The $\mathrm{P}$ doses were divided in three times a year, the first application being done in the planting pit and the others applied every four months. The MAP was used as the source of $\mathrm{P}$. The $\mathrm{N}$ of the plots that received the lowest dose of P (MAP) was compensated with urea application, since the MAP, in addition to the P, presents in its formula $9 \%$ of $\mathrm{N}$.
The banana tree was conducted with a family in each tussock (mother, daughter and granddaughter plants). The experiment was irrigated using the micro sprinkler system. The potassium chloride, urea, magnesium sulphate, zinc sulphate and boric acid were applied as covering in all plots (SILVA; BORGES, 2008).

In the plants beginning the bunch emission, in the first, second and third cycle of the banana tree, the $3^{\text {rd }}$ and $7^{\text {th }}$ leaves were collected from the apex, from where $10 \mathrm{~cm}$ from the center of the limbs were removed, eliminating the midrib, $10 \mathrm{~cm}$ from the petiole and $10 \mathrm{~cm}$ from the midrib. We also collected $10 \mathrm{~cm}$ from the 1 leaf limb. The harvested materials were placed in oven with forced air circulation at $70^{\circ} \mathrm{C}$ for 72 hours. The dry and ground material was analyzed and the P content determined (MALAVOLTA et al., 1997).

At the end of each banana cycle, soil samples were collected at depths of 0 to $0.20 \mathrm{~m}$, at the places where the fertilizers were applied, close to the useful plants of each plot, to analyze the $\mathrm{P}$ content available by Melich -1 extractor.

To detect the part of the leaf sensitive to P variation, regression equations were adjusted between the content of $\mathrm{P}$ determined in the parts of the leaves collected in function of the applied $\mathrm{P}_{2} \mathrm{O}_{5}$ doses and the available $\mathrm{P}$ in the soil. The part of the leaf that presented regression with a higher level of significance, of at least $10 \%$ of probability and greater value of $\mathrm{R}^{2}$ (coefficient of determination), was considered the diagnostic leaf.

The adjusted linear regressions between the midrib of the $3^{\text {rd }}$ leaf of the banana tree in function of the application of $\mathrm{P}$ doses in the soil were significant at 10 ; 5 and $5 \%$ probability in the first, second and third cycle, respectively (Figure 1). The adjusted regressions between the petiole of the $3^{\text {rd }}$ leaf and the $P$ doses applied to the soil were significant at $5 \%$ probability only in the second and third cycle (Figure 2) and the adjusted linear regressions between the midrib of the $7^{\text {th }}$ leaf in function of $\mathrm{P}$ doses application in the soil were significant at $5 \%$ probability only in the third cycle (Figure 3). There were no significant regression adjustments between the limb of the $3^{\text {rd }}$ leaf in function of the $\mathrm{P}$ doses applied to the soil in the three production cycles, confirming the results obtained by Silva \& Rodrigues (2013) and Bolfarini et al. (2016). The average $P$ contents found in the blade of the $3^{\text {rd }}$ leaf were $1.9 ; 1.8$ and $1.7 \mathrm{~g} \mathrm{~kg}^{-1}$ in the first, second and third cycles, respectively, presenting within the range of sufficiency (1.5 -1.9 $\mathrm{g} \mathrm{kg}^{-1}$ ) established by Silva et al. (2002). The regression adjustments between the $7^{\text {th }}$ leaf limb and the 1 leaf limb in function of the P doses applied to the soil were also not significant in the three production cycles.

The $\mathrm{P}$ content in the soil was linearly elevated with $\mathrm{P}$ doses applied to the soil (Figure 4) and the adjusted linear regressions between the $\mathrm{P}$ content in the midrib of the $3^{\text {rd }}$ leaf in function of the soil $P$ content were significant at $5 \%$ probability in the three production cycles (Figure $5 \mathrm{~A}, 5 \mathrm{~B}$ and $5 \mathrm{C}$ ), which indicates their sensitivity to detect 
the variation of $\mathrm{P}$ content in the soil as recommended by Lahav and Turner (1983).

The average $P$ contents obtained in the midrib of the $3^{\text {rd }}$ leaf from the apex were $1.07 ; 0.81$ and $0.93 \mathrm{~g} \mathrm{~kg}^{-1}$ in the first, second and third cycles, respectively, presenting an average content of $0.94 \mathrm{~g} \mathrm{~kg}^{-1}$. Lahav \& Turner (1983) presented a critical level of $0.80 \mathrm{~g} \mathrm{~kg}^{-1}$ for the $\mathrm{P}$ in the midrib of the $3^{\text {rd }}$ leaf of the Cavendish banana tree.
According to the results obtained, the conclusion is that the midrib of the $3^{\text {rd }}$ leaf has sensitivity to detect the variation of the $P$ content in the plant when the content of this nutrient varies in the soil, and can be indicated to be used in the diagnosis of $\mathrm{P}$ in the 'Prata anã' banana tree, and that the $3^{\text {rd }}$ leaf limb from the apex is not the part of the leaf indicated to perform the diagnosis of $\mathrm{P}$ in the 'Prata anã' banana, as recommended in the literature.

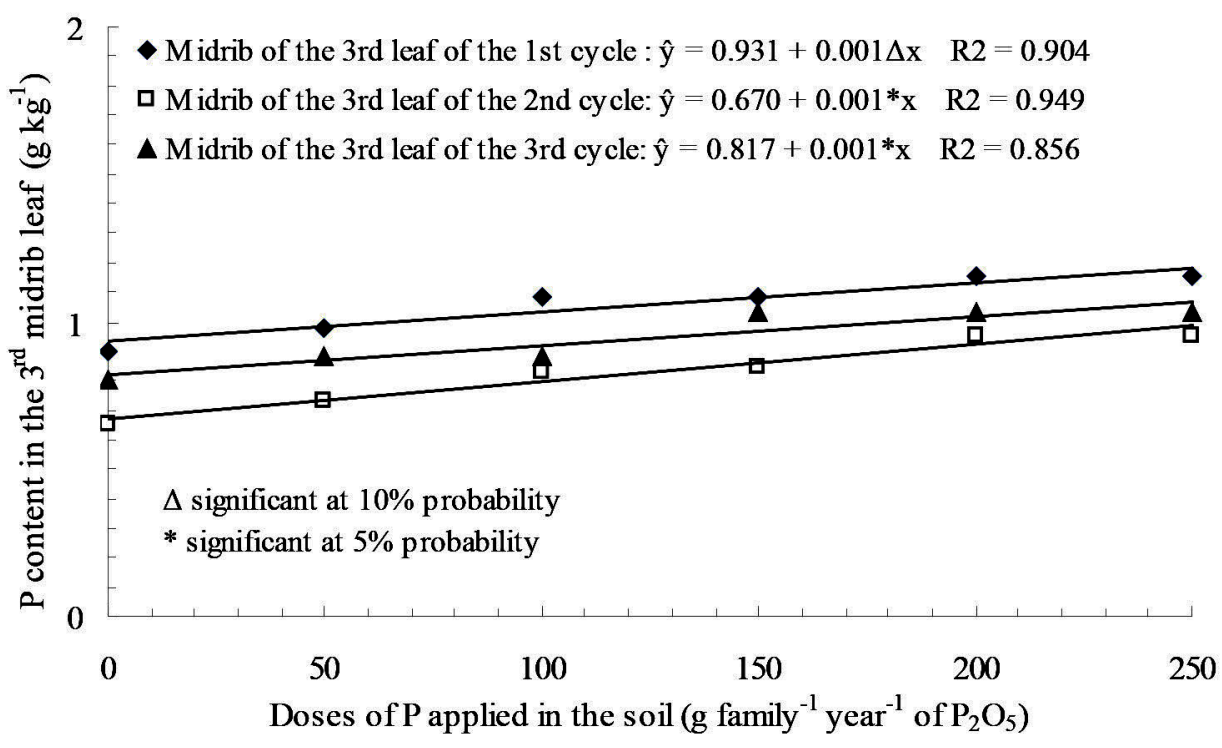

Figure 1. $\mathrm{P}$ content in the midrib of the $3^{\text {rd }}$ leaf of the 'Prata anã' banana in three production cycles in function of $\mathrm{P}$ doses applied to the soil.

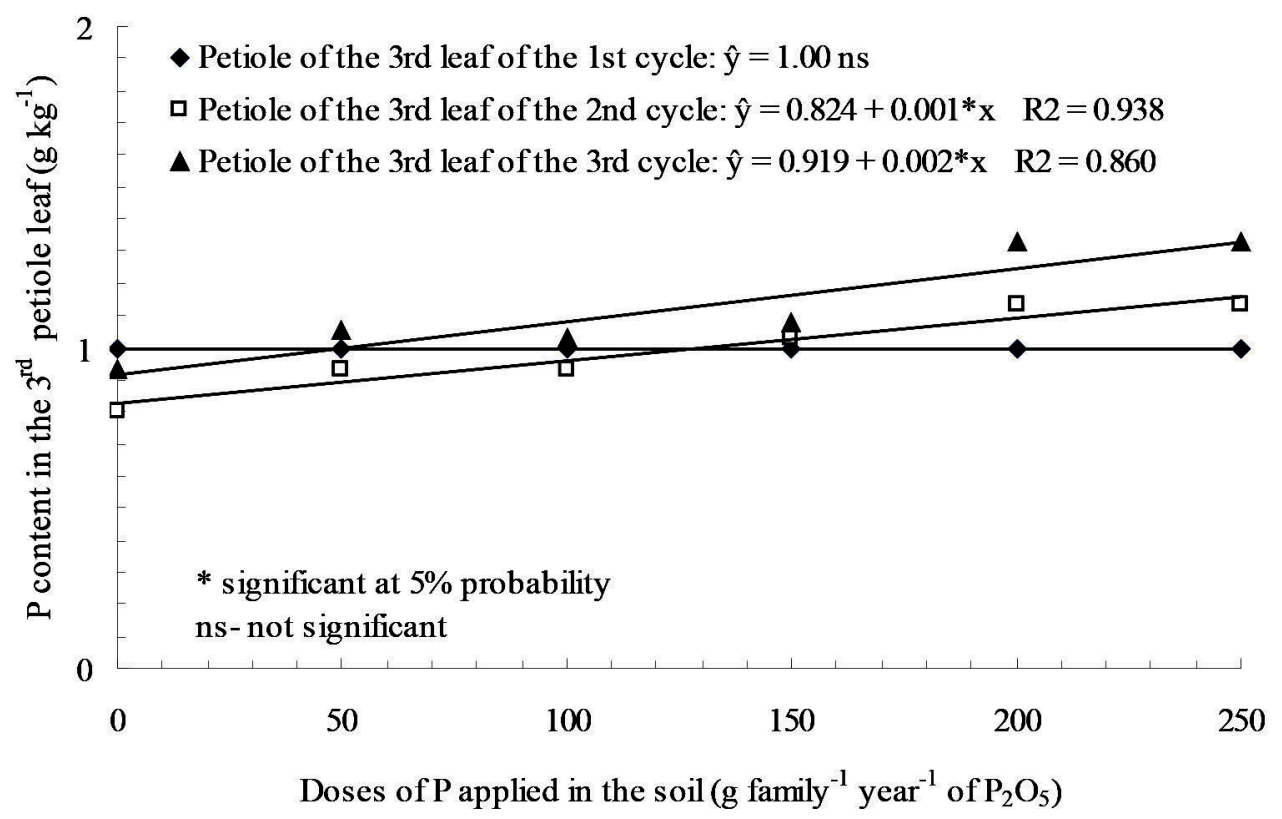

Figure 2. $\mathrm{P}$ content in the petiole of the $3^{\text {rd }}$ leaf of the 'Prata anã' banana in three production cycles in function of $\mathrm{P}$ doses applied to the soil. 


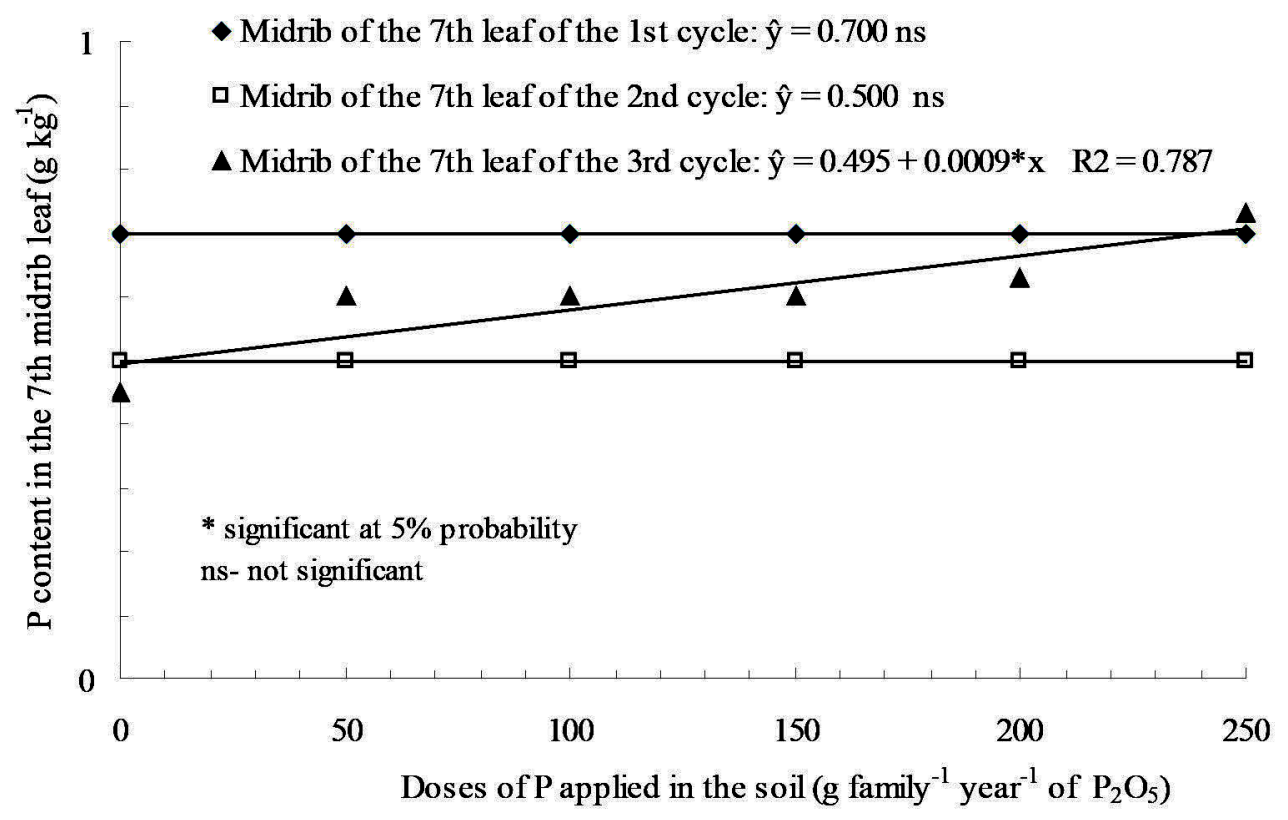

Figure 3. $\mathrm{P}$ content in the midrib of the $7^{\text {th }}$ leaf of the 'Prata anã' banana in three production cycles in function of $\mathrm{P}$ doses applied to the soil.

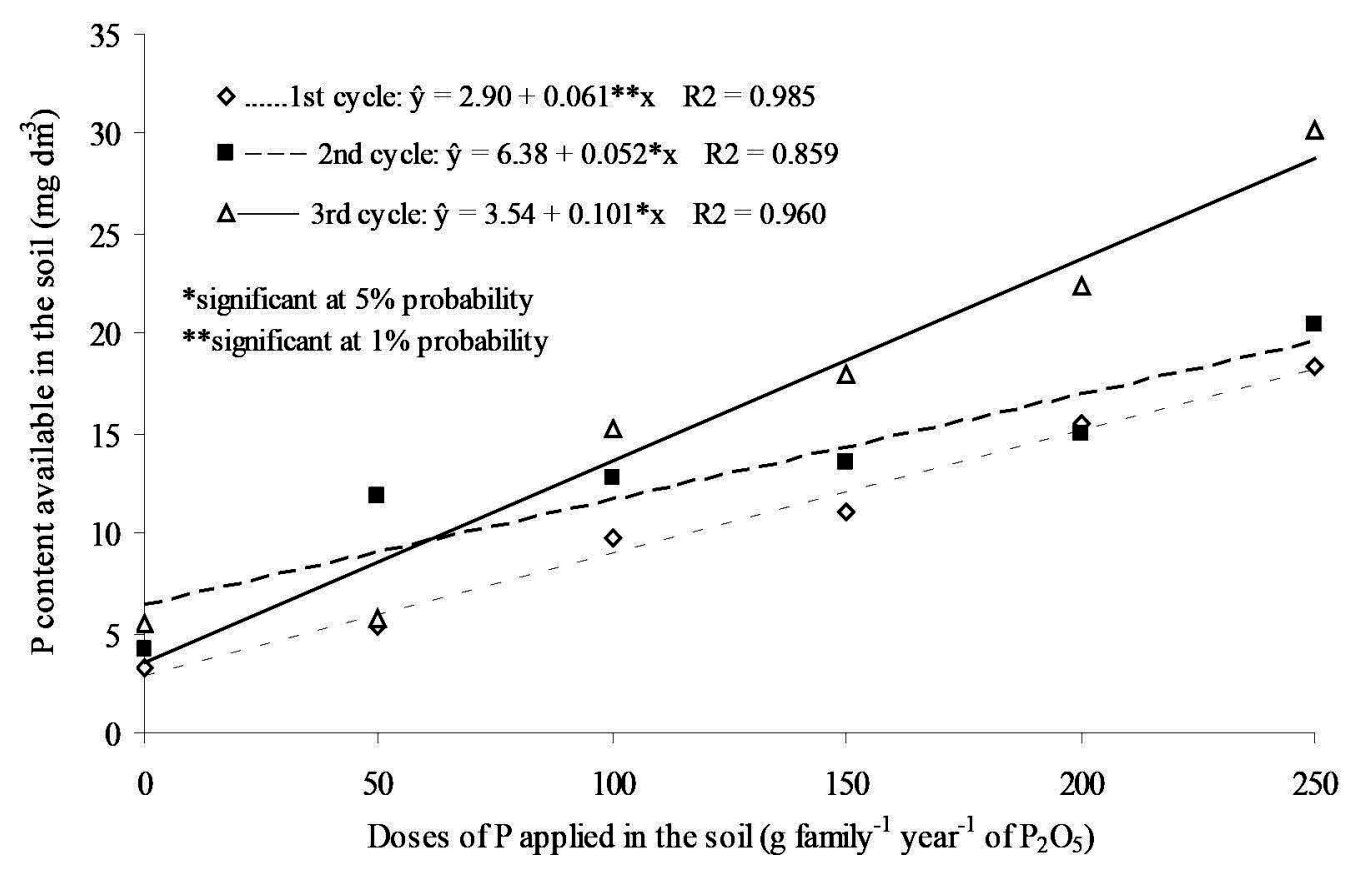

Figure 4. P content available in the soil in the depth of $0-0.2 \mathrm{~m}$ in function of $\mathrm{P}$ doses applied in the soil with 'Prata anã' banana. 

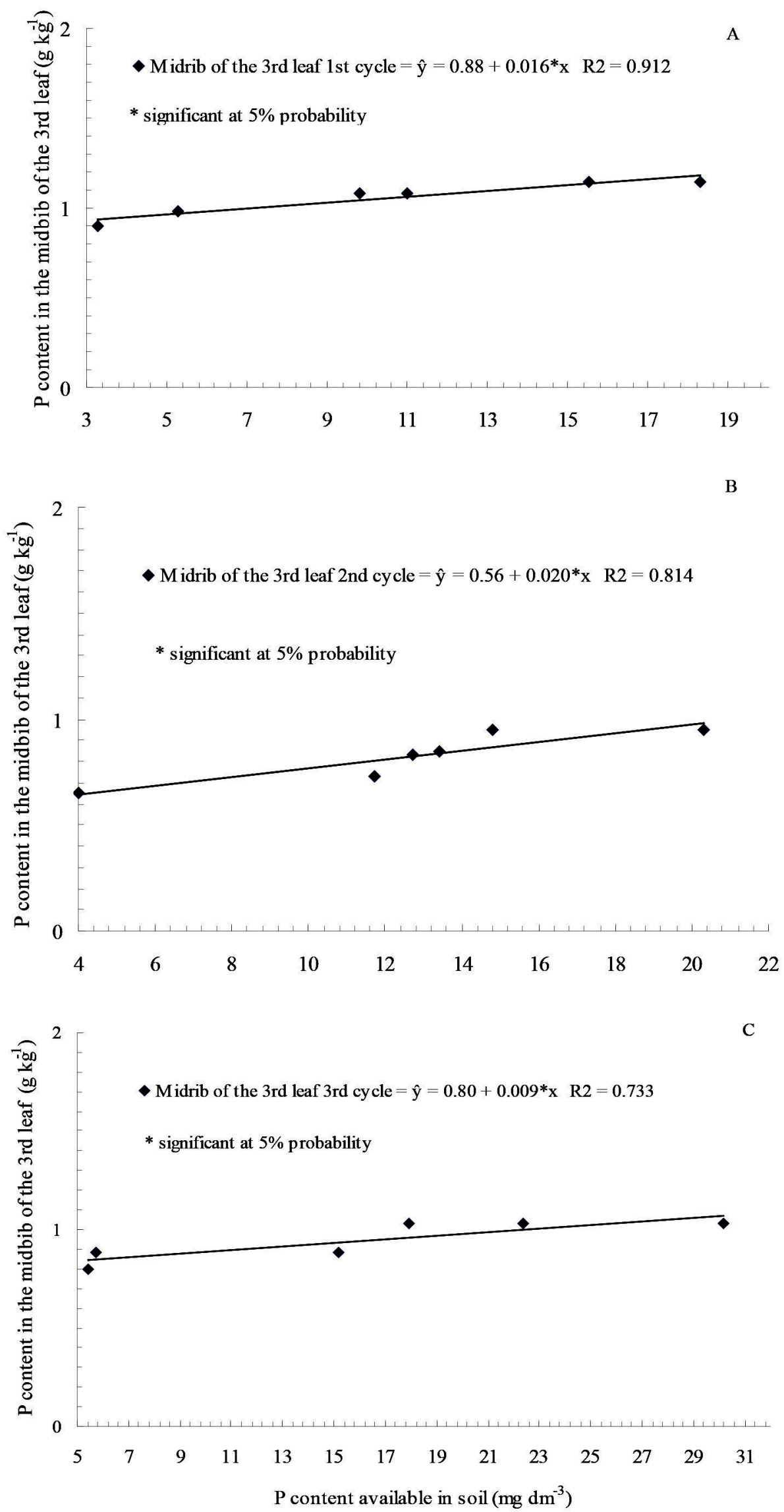

Figure 5. $\mathrm{P}$ content in the midrib of the $3^{\text {rd }}$ leaf of the 'Prata anã' banana tree in function of $\mathrm{P}$ available in the soil, first (A), second (B) and third cycle (C). 


\section{Acknowledgment}

We would like to thank the Foundation for Research Support of the State of Minas Gerais (Fapemig), for the financial support to carry out this research.

\section{References}

BOLFARINI, A.C.B.; LEONEL, S.LEONEL, M.; TECCHIO, M.A.; SILVA, M.S.SOUZA, J.M.A. Growth, yield and fruit quality of 'Maçã' banana under different rates of phosphorus fertilization. Australian Journal of Crop Science, Canberra, v.10, n.9, p.1368-1374, 2016.

LAHAV, E.; TURNER, D. W. Banana nutrition. Bern: International Potash Institute, 1983, 62p. (Bulletin, 7 ).

MALAVOLTA, E.; VITTI, C.G. OLIVEIRA, S.A. Avaliação do estado nutricional das plantas: princípios e aplicações. Piracicaba: POTAFOS, 1997. 201p.

MARTIN-PRÉVEL, P. Les méthode d'échantillonnage pour l'analyse foliaire du bananier. Fruits, Paris, v.29, n.9, p.583-588, 1974.

RODRIGUES, M. G. V.; PACHECO, D. D.; NATALE, W.; SILVA, J. T. A. Amostragem foliar da bananeira 'PrataAnã'. Revista Brasileira de Fruticultura. Jaboticabal - SP, v. 32, n. 1, p. 321-325, 2010.
SILVA, J.T.A. da; BORGES, A.L.; DIAS, M.S.C.; $\mathrm{COS} \neg$ TA, E.L. da; PRUDÊNCIO, J.M. Diagnóstico nutricional da bananeira 'Prata-Anã' para o Norte de Minas Gerais. Belo Horizonte: EPAMIG, 2002. 16p. (EPAMIG. Boletim Técnico, 70).

SILVA, J.T.A. da; BORGES A.L. Solo, nutrição mineral e adubação da bananeira. Informe Agropecuário, Belo Horizonte, v.29, p.23-34, 2008.

SILVA, J.T.A.; BORGES A.L., MALBURG, J.L. Solos, adubação e nutrição da bananeira. Informe Agropecuário, Belo Horizonte, v. 20, n. 196, p 21-36, 1999.

SILVA, J.T.A.; BORGES, A.L.; CARVALHO, J.G.; DAMASCENO, J.E.A. Adubação com potássio e nitrogênio em três ciclos de produção da bananeira Prata Anã. Revista Brasileira de Fruticultura, Jaboticabal, v.25, p.152-155, 2003.

SILVA, J.T.A.; RODRIGUES, M.G.V. Produção da bananeira 'Prata Anã' em função da aplicação de adubo fosfatado, em quatro ciclos. Pesquisa Agropecuária Brasileira, Brasília, DF, v.48, n.6, p.613-618, 2013. 